\title{
ACI33+ progenitor cells as gene delivery vehicle and cellular probe in subcutaneous tumor models: a preliminary study Ali M Rad ${ }^{1,2}$, ASM Iskander ${ }^{1}$, Branislava Janic ${ }^{1}$, Robert A Knight ${ }^{3}$, Ali S Arbab ${ }^{1}$ and Hamid Soltanian-Zadeh*1,4
}

Address: ${ }^{1}$ Department of Radiology, Henry Ford Hospital, Detroit, Michigan, USA, 2Department of Radiology, Massachusetts General Hospital/ Harvard Medical School, Boston, MA, USA, ${ }^{3}$ Department of Neurology, Henry Ford Hospital, Detroit, Michigan, USA and ${ }^{4}$ Control and Intelligent Processing Center of Excellence, Department of Electrical and Computer Engineering, University of Tehran, Tehran, Iran

Email: Ali M Rad - alirad@rad.hfh.edu; ASM Iskander - aiskander@rad.hfh.edu; Branislava Janic - bjanic@rad.hfh.edu; Robert A Knight - RKNIGHT1@hfhs.org; Ali S Arbab - saali@rad.hfh.edu; Hamid Soltanian-Zadeh* - hamids@rad.hfh.edu

* Corresponding author

Published: 27 March 2009

BMC Biotechnology 2009, 9:28 doi:10.1/86/1472-6750-9-28
Received: 22 August 2008

Accepted: 27 March 2009

This article is available from: http://www.biomedcentral.com/I472-6750/9/28

(C) 2009 Rad et al; licensee BioMed Central Ltd.

This is an Open Access article distributed under the terms of the Creative Commons Attribution License (http://creativecommons.org/licenses/by/2.0), which permits unrestricted use, distribution, and reproduction in any medium, provided the original work is properly cited.

\begin{abstract}
Background: Despite enormous progress in gene therapy for breast cancer, an optimal systemic vehicle for delivering gene products to the target tissue is still lacking. The purpose of this study was to determine whether $\mathrm{ACl} 33+$ progenitor cells (APC) can be used as both gene delivery vehicles and cellular probes for magnetic resonance imaging (MRI). In this study, we used superparamagentic iron oxide (SPIO)-labeled APCs to carry the human sodium iodide symporter (hNIS) gene to the sites of implanted breast cancer in mouse model. In vivo real time tracking of these cells was performed by MRI and expression of hNIS was determined by Tc-99m pertechnetate (Tc-99m) scan.
\end{abstract}

Results: Three million human breast cancer (MDA-MB-23I) cells were subcutaneously implanted in the right flank of nude mice. APCs, isolated from fresh human cord blood, were genetically transformed to carry the hNIS gene using adenoviral vectors and magnetically labeled with ferumoxides-protamine sulfate (FePro) complexes. Magnetically labeled genetically transformed cells were administered intravenously in tumor bearing mice when tumors reached $0.5 \mathrm{~cm}$ in the largest dimension. MRI and single photon emission computed tomography (SPECT) images were acquired 3 and 7 days after cell injection, with a 7 Tesla animal MRI system and a custom built micro-SPECT using Tc-99m, respectively. Expression of hNIS in accumulated cells was determined by staining with anti-hNIS antibody. APCs were efficiently labeled with ferumoxide-protamine sulfate (FePro) complexes and transduced with hNIS gene. Our study showed not only the accumulation of intravenously administered genetically transformed, magnetically labeled APCs in the implanted breast cancer, but also the expression of hNIS gene at the tumor site. Tc-99m activity ratio (tumor/non-tumor) was significantly different between animals that received non-transduced and transduced cells $(P<0.001)$.

Conclusion: This study indicates that genetically transformed, magnetically labeled APCs can be used both as delivery vehicles and cellular probes for detecting in vivo migration and homing of cells. Furthermore, they can potentially be used as a gene carrier system for the treatment of tumor or other diseases. 


\section{Background}

Breast cancer is the leading cause of death among women $[1,2]$. Against substantial research over the past decades, no definitive method for early detection and treatment of the breast cancer has been found. Gene therapy holds enormous therapeutic potential for breast cancer treatment [3-12]. In cancer gene therapy, viral vectors are administered locally or systematically [13]. Gene therapy using replication competent viral vectors could deliver their effects in two ways: 1 ) viral vectors can kill the tumor cells by infecting them and replicating inside cells (oncolysis); or 2) viral vectors can be used to insert therapeutic or suicidal genes, which can be targeted later $[11,14]$. When administered locally, however, the infiltrative nature of the breast cancer poses a problem for the successful delivery of genes to the sites of invading tumor cells. In addition, several factors, including lack of an efficient vector and delivery system, limit the effectiveness of systemically delivered genes. Very recently, progenitor cells have been used as carriers for therapeutic genes and are considered as delivery vehicles for transferring exogenous genes to the cancer cells $[15,16]$. In both cases, it is necessary to monitor the migration and homing of the genetically modified cells. However, current in vivo imaging techniques lack the ability to track the real time migration and homing of genetically altered cells to cancer tissue with acceptable resolution.

Labeling of cells with ferumoxides or other superparamagnetic iron oxides (SPIO) to track the migration of labeled cells is becoming routine in cellular MRI [17-22]. Recently, we have been able to magnetically label different mammalian cells including hematopoietic stem cells using two Food and Drug Administration (FDA) approved agents: ferumoxide and protamine sulfate. Ferumoxide is an incomplete dextran coated SPIO agent with an extremely high T2-relaxivity. It is used as contrast agent for liver diseases $[23,24]$. We have shown a linear correlation between relaxivity and iron concentration in labeled cells [25]. Protamine sulfate is used clinically as antidode for heparin toxicity. It has been shown that viability, functionality, and differentiation capacity of labeled cells (including stem cells) do not change after labeling $[19,26]$.

AC133+ cells are a subpopulation of CD34+ hematopoietic stem cells, which are believed to be more pluripotent, and incorporate into endothelial lining of neovessels in normal and pathological conditions [27]. The purpose of this study was to determine whether AC133+ progenitor cells (APCs) can be used as gene delivery/carrier vehicles and as cellular probes for MRI. We used superparamagentic iron oxide (SPIO)-labeled AC133+ progenitor cells (APCs) to carry the hNIS gene to sites of implanted breast cancer in a mouse model. In vivo real time tracking of cells was performed by MRI and expression of hNIS was determined by Tc-99m pertechnetate (Tc-99m) scan.

\section{Results}

Our experiments and data from other published papers indicate that MDA-MB-231 is a slow growing breast cancer cell line. Tumor Xenografts will appear in nude mice 6 to 7 days after inoculation and grow to 0.5 to $0.7 \mathrm{~cm}$ in 14 days [28]. Our data showed that the tumor can have internal bleeding or surface ulceration when it grows to more than $1.2 \mathrm{~cm}$ in a short period of time. Our main focus was to track the administered APCs at the sites of active angiogenesis in xenoplanted breast cancer, which is not related to the presence or absence of estrogen receptor.

\section{Efficiency of Iron Labeling}

Labeling efficiency with FePro complexes was more than $90 \%$, as determined by manual counting of PB-stained and unstained cells using a microscope.

\section{Mean Iron Concentration}

Mean intra-cellular iron concentration was measured based on a spectrophotometric method as described in the Method Section. The iron concentration was determined from three different batches of labeled cells, which were selected randomly during our experiments. The iron concentration was $8.4 \pm 2.8 \mathrm{pg}$ per cell.

\section{Viability of Labeled Cells}

Magnetically labeled genetically transduced APCs showed more than $75 \%$ viability compared to unlabeled nontransduced cells, whereas control unlabeled or labeled APCs were more than $90 \%$ viable.

\section{Efficiency of Viral Transduction}

Flowcytometric analysis indicated around 35\% transduction efficiency using adenoviral vectors containing EGFP gene (Figure 1). Follow up fluorescent microscopic examination indicated substantial number of EGFP positive cells even after 12 days (Figure 1).

\section{MRI Results}

MR images clearly showed the presence of low signal intensity areas around and inside the tumors in mice that received iron labeled cells compared with the tumors that received PBS only or unlabeled AC133+ cells, indicating the accumulation of administered cells (Figures 2 and 3 ). The presence of iron labeled cells was also confirmed by PB staining (Figures 2 and 3).

Immunohistochemistry confirmed the accumulation of NIS positive cells at the corresponding sites, as detected by FITC labeled secondary antibodies (Figure 2G). These findings prove that APCs can carry reporter or therapeutic genes to the site of interest. In this case, they were found 


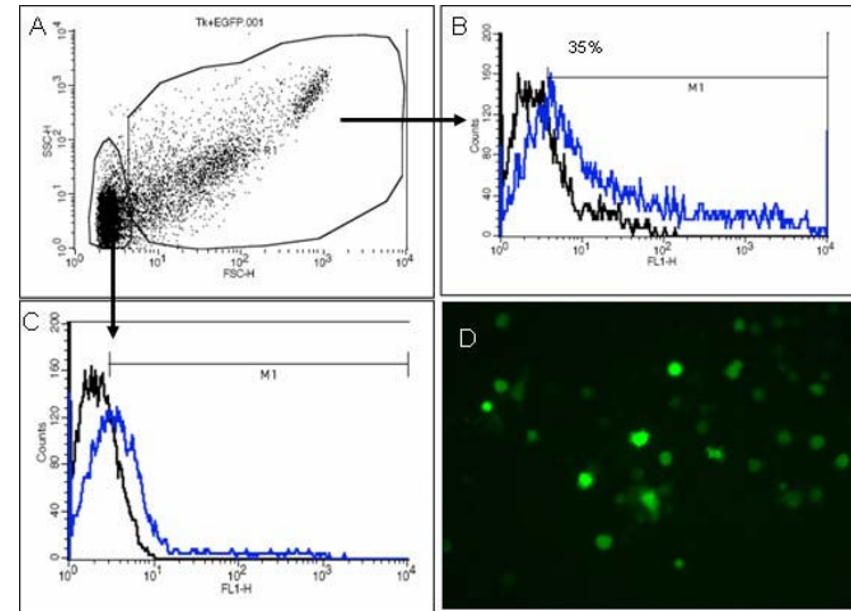

Figure I

Transfection efficiency using adenoviral vectors containing EGFP as a reporter gene. Flowcytometric analysis shows $30 \%$ to $35 \%$ EGFP positive cells in both cell populations. Fluorescent microscopy also shows EGFP positive cells in culture even after 12 days of infection.

at the periphery of the tumors where active angiogenesis was observed. The accumulated cells also showed the expression of endothelial markers such as CD31 (Figure $2 \mathrm{H})$.

\section{SPECT Analysis}

SPECT image analysis showed that the ratio of the total radioactivity (tumor/contralateral tissues) was significantly higher in animals that received transduced cells (Figures 2B, 2D) than those that received non-transduced cells (Figure 3A). A comparison of the ratio of radioactivity among the different groups of animals is shown in Figure 4. Significantly increased radioactivity ratios were observed in tumors of the animals that received magnetically labeled transgenic AC133+ cells compared to that of other groups both on days 3 and $7(p<0.05)$. There was no significant difference in radioactivity observed between days 3 and 7 in animals that received transgenic cells ( $p$-value $>0.05$ ). There were also no significant differences in the accumulated radioactivity in tumors observed among animals that received either labeled or unlabeled non-transgenic AC133+ cells. These findings indicate that the increased accumulation of radioactivity in tumors of animals that received transgenic cells is related to the expression of hNIS in the migrated and incorporated AC133+ cells. The hNIS bearing cells were also confirmed by immunohistochemistry.

Figure 4 reflects our observation of non-specific increased activity of Tc-99m at the site of tumors compared to the contralateral muscle in animals that received either only PBS or non-transduced unlabeled or labeled cells. This

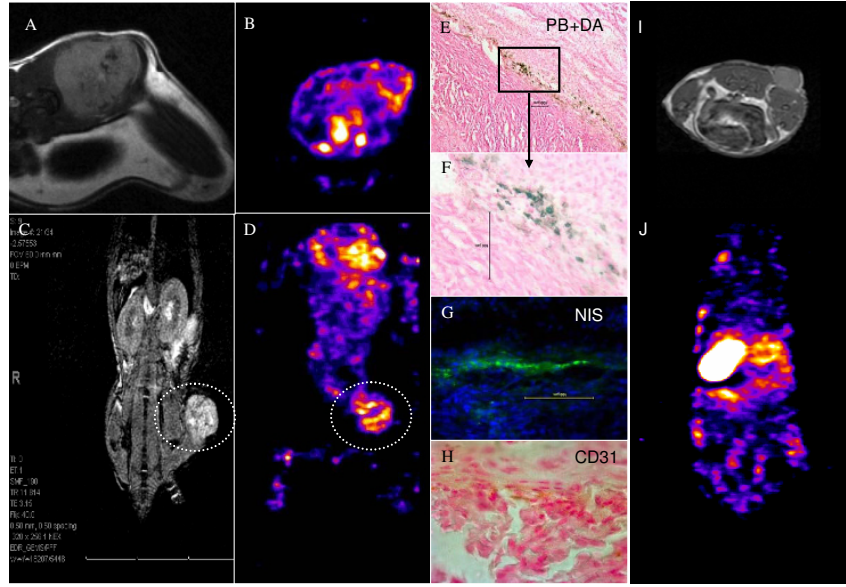

Figure 2

Accumulation of magnetically labeled, transgenic ACI33+ progenitor cells (APCs) around the

implanted tumor. MRI shows low signal intensity areas at the margin of the tumor $(A, C)$, which are at the corresponding sites of iron positive cells detected by Prussian blue staining $(E, F)$. The central low signal intensity areas are due to hemorrhagic foci within the tumor. $B$ (trans-axial sections) and $D$ (coronal sections) of SPECT studies indicate the accumulated transgenic APCs that are detected by T-99m (within the white dotted oval ROI). The SPECT study also proves the migration and homing of APCs at the margin of the tumors (seen on MRI). Immunohistochemistry shows the accumulation of NIS positive cells and CD3I positive cells at the corresponding sites, as detected by labeled secondary antibodies $(G, H)$. The findings prove that APCs can carry reporter or therapeutic genes to the site of interest (here at the site of active angiogenesis) and magnetically labeled APCs will act as probe for cellular MRI. MRI and SPECT of control unlabeled non-transduced $\mathrm{ACI} 33+$ progenitor cells $(\mathrm{I}, \mathrm{J})$

non-specific activity might be due to increased blood volume in the tumors and extravasations of Tc-99m. However, this non-specific activity was significantly lower than that found in tumors in animals that received transduced cells.

\section{Discussion}

Experimental results confirmed our hypotheses that magnetically labeled transgenic APCs can be used as cellular probes for MRI and gene carrier systems for breast cancer. Gene delivery vehicle is a key tool in cancer gene therapy. Carrier vehicles are needed for the delivery of therapeutic genes to the target cancer cells. These vehicles should be specifically targeted to the cancer cells. Lack of an appropriate carrier in addition to the infiltrative nature of breast cancer is one of the main limitations of successful breast cancer gene therapy [29]. To control the release of administered viruses into circulation, genetically transformed cells are being considered for gene therapy for different 


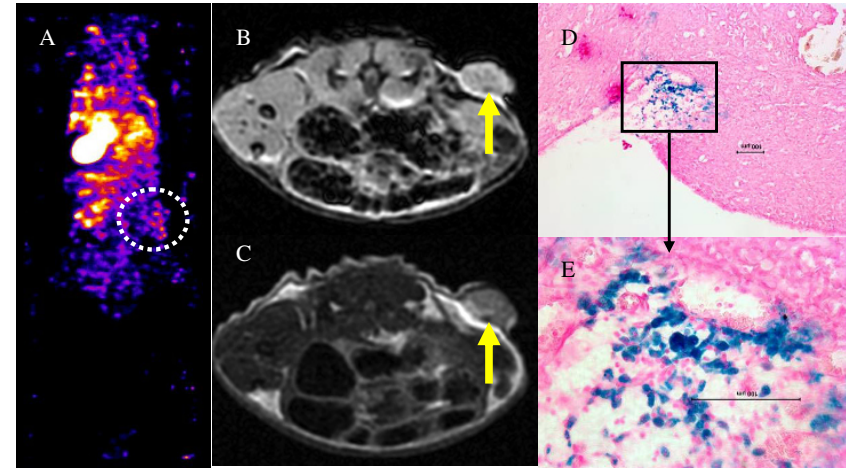

Figure 3

Accumulation of magnetically labeled, non-transgenic APCs around the implanted tumor 7 days after IV administration. (A) Coronal sections of SPECT data indicating non-significant activity of Tc-99m at the tumor site (within the white circular ROI). MRI shows low signal intensity areas at the periphery of the tumor ( $B, C$, arrows), which are at the corresponding sites of iron positive cells detected by Prussian blue staining $(D, E)$.

tumors [30-35]. Due to its unique property to migrate to the pathological lesions, stem cells are unique vehicles for delivering therapeutic genes to the tumors, especially for glioma [36-39]. Rat neural stem cells expressing the cytosine deaminase gene, injected at a site distant from the pri-

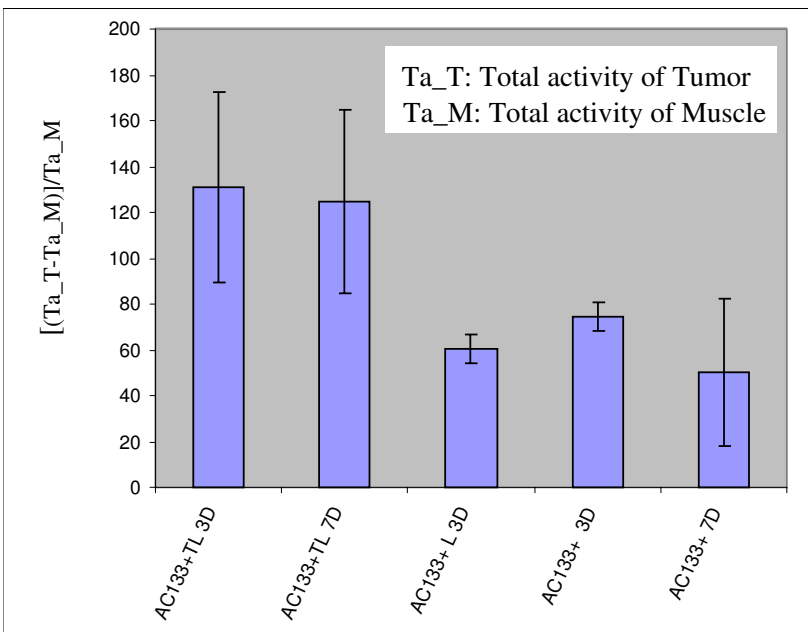

Figure 4

Quantitative analysis of the ratio of total radioactivity of tumor and contra-lateral muscle. There was no significant difference between total radioactivity of mice tumors injected by ACI33 labeled transduced cells in 3 or 7 days ( $p$-value $>0.05$ ). There was a significant difference between total radioactivity of the tumor with injected ed labeled cells and non-transduced cells for both $\mathrm{ACI} 33+$ only and ACI33+ labeled cells ( $\mathrm{p}$-value < 0.05). mary tumor exhibit extensive migration and stable expression of the gene, indicating persistent ability to destroy tumor cells locally as well as distal from the main tumor mass or metastatic foci [40]. Mesenchymal stem cells, pluripotent bone marrow stromal cells, are also used to carry genes to glioma and are considered effective delivery vehicles [39,41-43]. APCs, which are a subpopulation of pluripotent hematopoietic stem cells showed active migration and incorporation into the neovasculatures of tumor when administered locally or systemically $[17,27,44]$. Ferrari et al. [45] have shown the migration and incorporation of HSV-tk transduced mouse APCs in subcutaneous tumor in a mouse model, however, they did not show incorporation of the transduced cells by in vivo imaging. Our results support the findings of previous reports that transgenic stem cells can migrate and accumulate at the sites of implanted tumors $[46,47]$. However, the most important aspect of our study was that the transgenic cells were tracked by in vivo imaging (both by MRI and SPECT). To the best of our knowledge, this is the first study to use different imaging modalities to show the migration and accumulation of administered transgenic stem cells. The findings of this proof-of-principle study pave the road for further studies in other tumor models.

In recent years, imaging techniques that enable efficient and non-invasive in vivo monitoring and tracking of transplanted cells have become central to the development of cell transplantation based therapeutic approaches. Recent studies using various disease models demonstrated that MRI can be used as a high resolution imaging technique for in vivo cell tracking [17-20]. Furthermore, MRI has been successfully used to track the migration and incorporation of intravenously injected, magnetically labeled APCs into the blood vessels in rodent tumor model $[17,27]$. MRI along with the adequate labeling reagent allow for monitoring of the entire time course of APC migration. They also can show possible accumulation of labeled cells in different tissues. In vivo detection and measuring of gene expression using reporter genes is another imaging ability. Reporter gene methods provide a unique opportunity to study biology in living subjects. They also allow for monitoring of physiological events in an intact environment. NIS is a membrane glycoprotein that mediates active iodide uptake in thyroid gland and some other tissues [48]. Human NIS (hNIS) gene expression has been shown with radioisotopes of iodine and Tc99m-pertechnetate [49]. The hNIS has advantages over other reporter genes such as HSV1-tk and luciferase in that the hNIS gene product is innate and nonimmunogenic. It has limited endogenic tissue-specific expression and can mediate the uptake of chemically simple and available radiopharmaceuticals. We have shown that transduced APCs containing hNIS can easily be tracked and detected using Tc-99m and SPECT. This confirms that our cells are 
transduced by adenoviral vectors and hNIS is expressed in the APCs at the tumor sites. Tumor histology in addition to MRI analysis confirmed the presence of magnetically labeled and genetically transduced cells at the periphery of tumor where active angiogenesis was observed.

Limitations of this study are as follows. Viability of cells after viral transduction was one limitation, although our results were comparable to other published reports that used viral vectors for transduction of stem cells [50]. The overall transduction efficiency (we showed that 35\% of our cells were transduced), even with higher ratio of viral particles, was low in our case using adenoviral vectors because of a limited presence of CAR receptors on hematopoetic cells [51]. However, the transduction was relatively stable for at least 12 days. The use of lentiviral or retroviral vectors would likely have produced more transduced APCs [52]. Future projects will utilize different effective viral vectors for relative stable transduction. We are currently optimizing the virus-to-cell ratio to get more viable cells after transduction and to get higher transduction efficiency. The timing of cell injection is another variable that should be optimized. Multiple injections at different time points in the same animal should also be considered to increase the delivery of genes to the tumor site.

\section{Future Potential}

The stem cell gene delivery system has the potential to open a new window to the clinical cancer gene therapy. APCs can be collected from patient's own peripheral blood and bone marrow to avoid the immune system reaction. An important application of our gene delivery system is the delivery of suicidal genes to the cancer cells. In this approach, genes such as HSV-TK/acyclovir (ACV), ganciclovir (GCV), or herpes simplex virus-1-thymidine kinase (HSV-TK) convert a non-toxic pro-drug into a toxic drug. The bystander effect, a main phenomenon in this treatment modality, occurs when neighboring cancer cells, not specifically targeted with the suicidal gene, are also destroyed. The cell-to-cell transfer of phosphorylated GCV via gap junctions between HSV-TK transduced cells and neighboring non-infected cells is the primary mechanism for the bystander effect [53-55]. The efficacy of this protocol will be directly related to the gene/pro-drug combination and the target (cancer cells).

\section{Conclusion}

MRI and SPECT images showed accumulation of administered APCs in the implanted breast cancer and expression of hNIS gene, respectively. Our study indicates that APCs can carry therapeutic genes even after systemic administration. Genetically transformed, magnetically labeled APCs can be used both as delivery vehicles and cellular probes for detecting in vivo migration and homing of cells by MRI. This method can be used in the future development of gene therapy approaches where genetically modified cells can be tracked in real time and in vivo by MRI in different disease processes.

\section{Methods \\ ACI33+ progenitor cells (APCs)}

Fresh whole blood was obtained from the cord blood under IRB approved protocol with proper informed consent. Blood was collected in heparinized tubes. The blood was diluted 1:2 in phosphate buffered saline (PBS) plus 2 mM EDTA (Ethylenediaminetetraacetic Acid), layered onto lymphocyte separation medium (Ficoll, density $1.077 \mathrm{~g} / \mathrm{ml}$, ICN Biomedicals, Aurora, $\mathrm{OH}$ ) and centrifuged for 30 minutes at 1,900 RPM, and at a temperature of $20^{\circ} \mathrm{C}(35 \mathrm{ml}$ blood was very gently added onto $15 \mathrm{ml}$ lymphocyte separation medium in every $50 \mathrm{ml}$ sterile tube). Then, the white ring fraction (mononuclear cell layer) was transferred to a new $50 \mathrm{ml}$ tube using a sterile Pasteur pipette. PBS was added twice and the tubes were centrifuged for 15 minutes at 1500 RPM at room temperature. After discarding the supernatant, the pellet was resuspended in $4 \mathrm{ml}$ ACK lysine buffer to get rid of (for lysing) remaining erythrocytes. Mononuclear cells (MNCs) were incubated in the ACK lysine buffer for no more than 3 minutes on ice. After 3 minutes, $20 \mathrm{ml}$ PBS was added to the solution, the cells were washed twice (centrifuge at 1200 RPM) with PBS. MNCs were subjected to immunomagnetic separation using AC133 Cell Isolation Kit (Miltenyi Biotech; Auburn, CA; http:// www.miltenyibiotec.com), according to manufacturer's instruction [56,57]. Briefly, MNCs were incubated for 45 minutes on ice with an FcR-blocking reagent (human IgG) and AC133 MicroBeads. These microbeads are conjugated with monoclonal mouse anti-human antibodies against AC133. After washing with PBS plus $2 \mathrm{mM}$ EDTA, the labeled cells were filtered through a $30-\mu \mathrm{m}$ nylon mesh and loaded onto a column that was installed in a magnetic field. Trapped cells were eluted after the column was removed from the magnet. The collected cells were named AC133+ progenitor cells (APCs). APCs were grown in stemline II media (Sigma, St. Louise, MO) supplemented with $10 \mathrm{ng} / \mathrm{ml}$ of thrombopoietin (TPO), $40 \mathrm{ng} / \mathrm{ml}$ of FLT3 and $40 \mathrm{ng} / \mathrm{ml}$ of stem cell factor (SCF). Initially, the cells were suspended in media at $1 \times 10^{6}$ per $\mathrm{ml}$ and grown in $5 \% \mathrm{CO}_{2} / 95 \%$ air at $37^{\circ} \mathrm{C}$ in a humidified incubator with fresh media added on every third day. The cells were propagated for 7-10 days. On the day of labeling, the cells were harvested and resuspended at a concentration of $4 \times$ $10^{6}$ cells per ml. Collected cells were analyzed at different days in culture for their phenotypical expression. There were gradual declines in the expression of CD133 and CD34, but the majority of cells were positive for CD31, CXCR4 and CD117. Markers of lymphocytic (CD3, CD19) and monocytic (CD14) lineages were absent. 


\section{Breast Cancer Cells (MDA-MB-23I)}

Breast cancer cells (MDA-MB-231, ATCC, VA) were cultured in $75-\mathrm{cm}^{2}$ tissue culture flasks with Dulbecco's modified Eagle's medium (DMEM) supplemented with 10\% fetal bovine serum, penicillin (100 IU/mL), and streptomycin $(100 \mu \mathrm{g} / \mathrm{mL})$ until they were $80-90 \%$ confluent.

\section{Tumor Implantation}

All animal studies were approved by the institutional animal care and user committee at Henry Ford Health System. Female nude mice (total 48 mice) were used for implantation of tumor cells. Tumor cells (human breast cancer), cultured in-vitro were harvested by trypsinization and centrifugation, washed twice with PBS buffer, and then resuspended in cell culture serum free media at a concentration of $6 \times 10^{7}$ cells $/ \mathrm{ml}$. The animals received one subcutaneous injection of $50 \mu \mathrm{l}$ of cell suspension ( 3 million cells) in the right hind flank. These tumor cells are efficient in making xenografted tumors with almost $90 \%$ efficiency and show marked vascularity with less central necrosis. Tumors were measured twice a week after implantation in two dimensions. All animals received intravenous injection of APCs when the tumor measured between 0.5 to $1 \mathrm{~cm}$ diameter in the largest dimension.

\section{Transduction of APCs with Adenoviral Vector Containing HSV-tk and hNIS Genes}

An adenoviral vector carrying either the hNIS or EGFP gene was used to transduce cells (Figure 5). Both vectors also contained the HSV-tk gene, which can be used as a suicidal gene for therapeutic purposes. hNIS and EGFP acted as reporter genes and their activities were determined by Tc-99m pertechnetate (Tc-99m) SPECT and flowcytometer, respectively. Cell to viral particle ratio was
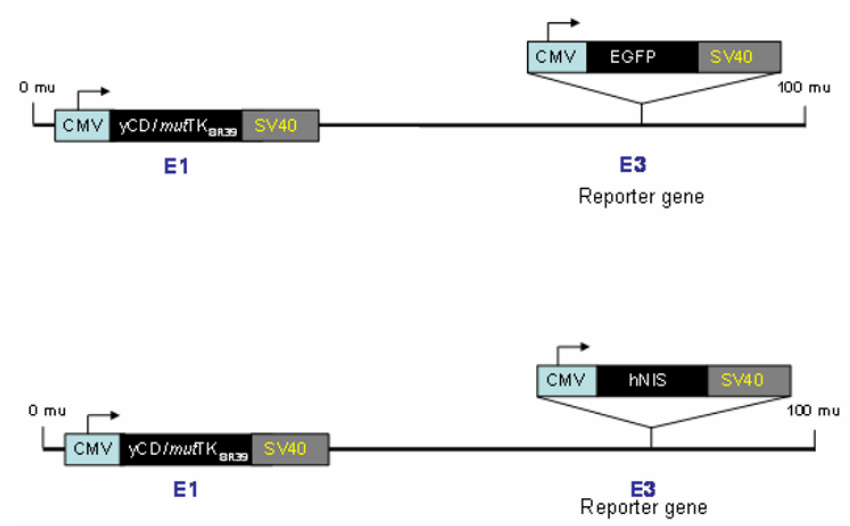

Figure 5

Adenovirus design to detect transfected efficiency by flowcytometric (EGFP) and nuclear medicine (hNIS using Tc-99m) techniques. This figure is printed with the permission of Kenneth $\mathrm{N}$ Barton from the Radiation Oncology Department of Henry Ford Hospital. maintained at 1:1000. Cells were at a concentration of 10 million per $\mathrm{ml}$ for initial 1 hour and then diluted $\times 10$ with complete culture media. Transduction efficiency was determined on day 3 by flowcytometric analysis (using EGFP as reporter gene) and fluorescent microscope. These transgenic cells were magnetically (FePro) labeled on day 4 after transduction.

\section{Labeling of Cells with Ferumoxide-Protamine Sulfate (FePro) Complex}

The commercially available, FDA-approved SPIO, ferumoxide suspension, (Feridex IV ${ }^{\circledR}$, Berlex Laboratories, Inc, Wayne, New Jersey) contains particles approximately 80 $150 \mathrm{~nm}$ in size and has a total iron content of $11.2 \mathrm{mg} / \mathrm{ml}$. Protamine sulfate (American Pharmaceuticals Partner Inc. Schaumburg, IL), supplied at $10 \mathrm{mg} / \mathrm{ml}$, was prepared as a fresh stock solution of $1 \mathrm{mg} / \mathrm{ml}$ in distilled water at the time of use. Ferumoxide, at a concentration of $100 \mu \mathrm{g} / \mathrm{ml}$, was put into a mixing flask or tube containing serum-free RPMI 1640 medium (Biosource, Camarillo, CA) containing non-essential amino acid, sodium pyruvate, and Lglutamine. Protamine sulfate was then added to the solution at a concentration of $3-4.5 \mu \mathrm{g} / \mathrm{ml}$ of mixing media. The solution containing ferumoxide and protamine sulfate was mixed for 30 seconds with intermittent hand shakings. After 30 seconds, the FePro complex was added directly to the cells, incubated for 2-3 hours, and then an equal volume of the complete medium was added to the cells, for a final concentration of $50 \mu \mathrm{g}$ ferumoxide $/ \mathrm{ml}$ of medium. The cell suspension was then incubated overnight. After overnight incubation, the cells were washed three times and then resuspended in PBS.

\section{Measuring Intracellular Iron}

Intracellular iron concentration was measured based on our previously published method by UV/VIS spectrophotometry [58]. In brief, cell suspensions with known cell density were demineralized in $1 \mathrm{ml}$ of $5 \mathrm{Mol} / \mathrm{L}$ hydrochloric acid for 4 hours. Then, the color of the mixture was read with a UV/VIS spectrometer at $351 \mathrm{~nm}$ wave-length. The absorption value was normalized to a standard curve generated from a known solution of ferumoxide. To determine the very low concentration of iron in the sample, the iron concentration was measured using this method and is expressed as an average picogram of iron/cell. Currently, this method is used in our laboratory to determine the very low concentration of iron in the sample. The commercially available kit for measuring iron concentration was not sensitive enough to detect such low iron concentrations $(<1 \mu \mathrm{g} / \mathrm{ml})$.

\section{Determination of Labeling Efficiency}

After incubation with FePro, the cells were washed 3 times in the presence of heparin sulfate to remove excess FePro and transferred to cytospin slides. Cells were fixed and 
stained with Perl's reagent for Prussian blue (PB) staining. FePro labeling efficiency was determined by manually counting PB stained and unstained cells using a microscope at $40 \times$ magnification. Cells were considered PB positive if intracytoplasmic blue granules were detected. The percentage of labeled cells was determined from the average of 5-10 high-powered fields.

\section{Cellular viability of FE-Pro labeled cells}

After labeling, the cells were washed at least twice with sterile PBS and then resuspended in PBS at a concentration of $3 \times 10^{7}$ cells $/ \mathrm{ml}$. A small aliquot of cells were mixed with trypan blue dye and checked under a microscope to determine cell viability.

\section{Intravenous Administration of hNIS Transduced and FePro Labeled APCs}

Either hNIS transduced and FePro labeled APCs or control APCs (without transduction and labeling) were administered intravenously into tail vein of mouse when the tumor grew to $0.5 \mathrm{~cm}$ in size (along the largest dimension). A total of three million APCs in $200 \mu \mathrm{l}$ was administered intravenously. Following administration of APCs, mice underwent MRI and Tc-99m SPECT scanning to determine the migration and accumulation of FePro labeled and transgenic (containing hNIS) cells, respectively, on days 3 and 7 after cell administration.

\section{Magnetic Resonance Imaging Study \\ Preparation}

Anesthesia was induced and maintained during all MRI studies using an inhalation mixture of isoflurane $(3 \%$ for induction and $0.5-1.5 \%$ for maintenance) in a $2: 1 \mathrm{~N}_{2} \mathrm{O} /$ $\mathrm{O}_{2}$ gas mixture, with the animal breathing spontaneously. After induction, the animal was placed in a custom made MRI compatible Plexiglas holder that was equipped a nose cone for the delivery of gasses and a heating pad. After securing the animal's nose inside the mask, the hindquarters of the animal were positioned and secured to the holder, a rectal probe was inserted for temperature monitoring, and the holder was placed inside the imaging coil. Next, the animal holder/imaging coil assembly was placed inside the magnet, isoflurane was reduced to $0.5-$ $1.5 \%$, and the animal's core temperature maintained at $37^{\circ} \mathrm{C}$ using a feedback controlled water bath.

\section{MRI Systems}

MRI experiments were conducted using either a 7 Tesla (7 T) or a 3 Tesla (3 T) MRI system. The 7 T system is a $12 \mathrm{~cm}$ (clear bore) magnet (Magnex Scientific, Inc., Abingdon, UK) interfaced to a Bruker console (Bruker Biospin MRI, Inc, Billerica, MA) with actively shielded gradients of 25 gauss $/ \mathrm{cm}$ and $100 \mu$ sise time. A $5 \mathrm{~cm}$ diameter quadrature birdcage RF coil tuned to $300 \mathrm{MHz}$ is used for RF transmission and reception. The $3 \mathrm{~T}$ system is a whole body magnet (Signa Excite, GE health, Milwaukee, WI) that uses dedicated small animal coils (Doty scientific) for animal imaging. Once inside the magnet, the position of the animal was adjusted so that the central imaging slice coincided with the center of the tumor.

\section{T2 Measurement using 7 T System}

Multi-slice T2-weighted images were acquired using a multi-echo spin-echo sequence with a fixed repetition time (TR) and progressively incremented echo times (TE) $[\mathrm{TR} / \mathrm{TE}=3000 / 12,24,36,48 \mathrm{~ms}]$. Imaging parameters were as follows: $\mathrm{FOV}=32 \mathrm{~mm}$, matrix $=256 \times 256,17$ slices (interleaved slice acquisition), slice thickness $=1$ $\mathrm{mm}$. The total scan time was approximately 13 minutes.

\section{Susceptibility Weighted Imaging (SWI) using 7 T System}

This is a specialized 3D gradient-echo sequence, very sensitive to the presence of iron and can detect iron labeled cells. The method uses TR/TE $=50 \mathrm{~ms} / 6.7 \mathrm{~ms}$, flip angle = 15 degrees, $\mathrm{BW}=50 \mathrm{KHz}, 32 \times 32 \times 16 \mathrm{~mm}^{3} \mathrm{FOV}, 256 \times$ $256 \times 64$ matrix (resolution of $125 \times 125 \times 250 \mathrm{~mm}^{3}$ ), 2 averages with flow compensation applied in all three directions. The total scan time for this $3 \mathrm{D}$ data set was approximately 27 minutes.

\section{T2 Measurement using 3 T System}

Multi-slice T2 images were acquired using a Carr, Purcell, Meiboom, and Gill (CPMG) multi-echo spin-echo sequence with a fixed repetition time (TR) and progressively incremented echo times (TE) $[\mathrm{TR} / \mathrm{TE}=2400 / 15,30$, $45,60 \mathrm{~ms}$. The imaging parameters were as follows: FOV $=35 \mathrm{~mm}$, matrix $=160 \times 128$, averages $=3,15$ slices, slice thickness $=1 \mathrm{~mm}$. The total scan time was approximately 5 minutes.

\section{T2* Measurements using 3 T System}

Multi-slice T2* images were acquired using a multi-echo gradient-echo sequence with a fixed repetition time (TR) and progressively incremented echo times (TE) $[\mathrm{TR} / \mathrm{TE}=$ $600 / 10,15,20,30 \mathrm{~ms}$. The imaging parameters were as follows: $\mathrm{FOV}=35 \mathrm{~mm}$, matrix $=160 \times 128$, averages $=4$, 15 slices, slice thickness $=1 \mathrm{~mm}$. The total scan time was approximately 8 minutes.

\section{FIESTA using 3 T System}

This is a specialized 3D gradient-echo sequence, very sensitive to the presence of iron and can detect iron labeled cells. The method uses TR/TE $=11-15 \mathrm{~ms} / 3-7 \mathrm{~ms}$, flip angle $=40$ degrees, $\mathrm{BW}=10 \mathrm{kHz}, 60 \times 60 \times 40 \mathrm{~mm}^{3} \mathrm{FOV}$, $300 \times 300 \times 200$ matrix (resolution of $200 \times 200 \times 200$ $\mathrm{mm}^{3}$ ), 2 averages. The total scan time for this $3 \mathrm{D}$ data set was approximately 15 minutes.

\section{SPECT Study}

Within 24 hours after MRI, animals underwent SPECT studies using Tc-99m to determine the status of genetically transformed cells at the sites of tumors. Animals were 
anesthetized using ketamine/xylazine $(100 / 15 \mathrm{mg} / \mathrm{kg})$ and received $1 \mathrm{mCi}$ of Tc-99m through tail vein injection in a volume of $200 \mu \mathrm{l}$. 60 minutes after Tc-99m injection, animals were wrapped with padded sheet to keep them warm and placed in the imaging holder under anesthesia. SPECT images were acquired with a dedicated PRISM 3000 gamma camera fitted with mutli-pinhole mouse collimator, 360 degree rotation with 36 degree increments, $180 \mathrm{sec}$ per projection, using $256 \times 256$ matrices with a field of view of $4 \times 6 \mathrm{~cm}$. The total time required for acquiring SPECT images was about 31 minutes.

\section{Euthanasia and Histological Analysis}

Immediately after SPECT imaging, the animals were anesthetized using pentobarbital $(100 \mathrm{mg} / \mathrm{kg}$ intravenous or intraperitoneal) and sacrificed. The tissues were fixed for histological analysis by perfusion with saline, for vascular washout, followed by paraformaldehyde. The radioactive fluids were collected and contained in a shielded area to decay. The animals were euthanized either with $100 \mathrm{mg} /$ $\mathrm{kg}$ of pentobarbital administration (intravenous or intraperitoneal). The whole tumor and part of surrounding tissues (muscles and skin) were collected for histochemical determination of iron labeled cells using PB staining and markers of endothelial cells, such as CD31 and vWF using human specific antibodies (BD Pharmingen and DakoCytomation respectively). Expression of hNIS in accumulated cells was determined by staining with anti-hNIS antibody (Genetex, TX, USA).

\section{Study Design}

There were four groups of animals ( $n=6 /$ group) for each time point (days 3 and 7 after IV administration of cells): 1) controls injected with PBS: 2) tumors injected with unlabeled APCs; 3) tumors injected with magnetically labeled APCs; and 4) tumors injected with transduced and magnetically labeled APCs. The total number of animals used in the study was 48 .

\section{Image and Statistical Analysis}

Eigentool image analysis software (Henry Ford Hospital, Detroit, MI, USA) was used to analyze MRI images. Eigentool has a comprehensive set of functions for displaying, restoring, enhancing, and analyzing images [59-61]. Statistical analysis of SPECT images was performed with SPSS software (version 13; SPSS Institute Inc.) for Microsoft Windows. The data were analyzed with two-way analysis of variance and general linear models. The significance level was set at 0.05 and statistical analysis of the tumorto-muscle ratio was performed with constructed SPECT images. ImageJ software was also used for SPECT analysis. Tumor volume was defined on the SPECT images by drawing ROIs around the tumor on each slice and the total activity was recorded. The same volume was used to com- pute the total activity from the contra-lateral muscle region.

The percentage of change in the total activity $(\Delta \mathrm{Ta} \%)$ was calculated using:

$$
\Delta \mathrm{Ta} \%=100 \times(\mathrm{TaT}-\mathrm{TaM}) / \mathrm{TaM}
$$

where TaT is the total activity of the tumor and TaM is the total activity of the contralateral muscle for the same volume as that of the tumor.

\section{Abbreviations}

APC: AC133+ progenitor cells; SPIO: superparamagnetic iron oxide; MRI: Magnetic resonance imaging; hNIS: human sodium iodide symporter; FePro: ferumoxidesprotamine sulfate; SPECT: single photon emission computed tomography; FDA: Food and Drug Administration; PBS: phosphate buffered saline; EDTA: Ethylenediaminetetraacetic Acid; TPO: thrombopoietin, SCF: stem cell factor; MNCs: Mononuclear cells; DMEM: Dulbecco's modified Eagle's medium; PB: Prussian blue; ACV: acyclovir; GCV: ganciclovir; HSV-TK: herpes simplex virus-1-thymidine kinase; EGFP: Enhanced Green Fluorescent Proteins.

\section{Authors' contributions}

AMR carried out the experimental design, isolation of stem cells, tumor implantation, cell transduction and labeling, MRI and SPECT imaging, data analysis, and initial manuscript preparation. ASMI participated in the isolation of stem cells, tumor implantation, stem cell injection, and histology. BJ participated in the cell transduction and labeling. RAK participated in the MRI and manuscript preparation. ASA provided intellectual support and participated in the experimental design, analysis of MRI and SPECT, and manuscript preparation. HSZ provided intellectual support and helped with image processing and manuscript preparation. All authors read and approved the final manuscript.

\section{Acknowledgements}

This work was supported in part by the Department of Defense Breast Cancer Research Program under grant number W8IXWH-06-I-0576 and by the National Institutes of Health $(\mathrm{NIH})$ under grant numbers EB002450, CAI2203I, and NS058589.

\section{References}

I. Uray IP, Brown PH: Prevention of breast cancer: current state of the science and future opportunities. Expert Opin Investig Drugs 2006, I 5(12): I583-1600.

2. Gotzsche PC, Nielsen M: Screening for breast cancer with mammography. Cochrane Database Syst Rev 2006:CD00I877.

3. Bergman I, Griffin JA, Gao Y, Whitaker-Dowling P: Treatment of implanted mammary tumors with recombinant vesicular stomatitis virus targeted to Her2/neu. Int J Cancer 2007, I 2 I (2):425-430.

4. Chan T, Sami A, El-Gayed A, Guo X, Xiang J: HER-2/neu-gene engineered dendritic cell vaccine stimulates stronger HER-2/ 
neu-specific immune responses compared to DNA vaccination. Gene therapy 2006, I3(19):|39|-1402.

5. Israyelyan AH, Melancon JM, Lomax LG, Sehgal I, Leuschner C, Kearney MT, Chouljenko VN, Baghian A, Kousoulas KG: Effective treatment of human breast tumor in a mouse xenograft model with herpes simplex virus type I specifying the NVI020 genomic deletion and the gBsyn 3 syncytial mutation enabling high viral replication and spread in breast cancer cells. Human gene therapy 2007, I8(5):457-473.

6. Kommareddy S, Amiji M: Antiangiogenic gene therapy with systemically administered sFIt-I plasmid DNA in engineered gelatin-based nanovectors. Cancer gene therapy 2007, I 4(5):488-498.

7. Lim SJ, Paeng JC, Kim SJ, Kim SY, Lee H, Moon DH: Enhanced expression of adenovirus-mediated sodium iodide symporter gene in MCF-7 breast cancer cells with retinoic acid treatment. J Nucl Med 2007, 48(3):398-404.

8. Magnusson MK, Henning P, Myhre S, Wikman M, Uil TG, Friedman M, Andersson KM, Hong SS, Hoeben RC, Habib NA, et al.: Adenovirus 5 vector genetically re-targeted by an Affibody molecule with specificity for tumor antigen HER2/neu. Cancer gene therapy 2007, I4(5):468-479.

9. Pastorakova A, Hlubinova K, Altaner C: Treatment of human tumor cells by combine gene therapy harnessing plasmids expressing human tumor necrosis factor alpha and bacterial cytosine deaminase suicide gene. Neoplasma 2006, 53(6):478-484.

10. Stoff-Khalili MA, Dall P, Curiel DT: Gene therapy for carcinoma of the breast. Cancer gene therapy 2006, I3(7):633-647.

II. Takahashi S, Ito Y, Hatake K, Sugimoto Y: Gene therapy for breast cancer. - Review of clinical gene therapy trials for breast cancer and MDRI gene therapy trial in Cancer Institute Hospital. Breast cancer (Tokyo, Japan) 2006, I3(I):8-15.

12. Takahashi S, Sugimoto Y: [Gene therapy for breast cancer]. Nippon Rinsho 2007, 65(Suppl 6):|35-|4|.

13. Ebert O, Harbaran S, Shinozaki K, Woo SL: Systemic therapy of experimental breast cancer metastases by mutant vesicular stomatitis virus in immune-competent mice. Cancer gene therapy 2005, I 2(4):350-358.

14. Gadal F, Bastias J, Wei MX, Crepin M: "Suicide" gene therapy of breast cancer cells is only cytostatic in vitro but anti-tumoral in vivo on breast MCF7-ras tumor. In vivo (Athens, Greece) 2004, | 8(6):8|3-8|8.

15. Gomez-Navarro J, Contreras JL, Arafat W, Jiang XL, Krisky D, Oligino T, Marconi P, Hubbard B, Glorioso JC, Curiel DT, et al: Genetically modified CD34+ cells as cellular vehicles for gene delivery into areas of angiogenesis in a rhesus model. Gene therapy 2000, 7(I):43-52.

16. Morizono K, De Ugarte DA, Zhu M, Zuk P, Elbarbary A, Ashjian P, Benhaim $P$, Chen IS, Hedrick MH: Multilineage cells from adipose tissue as gene delivery vehicles. Human gene therapy 2003, I 4(1):59-66

17. Anderson SA, Glod J, Arbab AS, Noel M, Ashari P, Fine HA, Frank JA: Noninvasive MR imaging of magnetically labeled stem cells to directly identify neovasculature in a glioma model. Blood 2005, I 05(I):420-425.

18. Anderson SA, Shukaliak-Quandt J, Jordan EK, Arbab AS, Martin R, McFarland $H$, Frank JA: Magnetic resonance imaging of labeled T-cells in a mouse model of multiple sclerosis. Ann Neurol 2004, 55(5):654-659.

19. Arbab AS, Jordan EK, Wilson LB, Yocum GT, Lewis BK, Frank JA: In vivo trafficking and targeted delivery of magnetically labeled stem cells. Human gene therapy 2004, I 5(4):35 1-360.

20. Arbab AS, Liu W, Frank JA: Cellular magnetic resonance imaging: current status and future prospects. Expert Rev Med Devices 2006, 3(4):427-439.

21. Frank JA, Anderson SA, Kalsih H, Jordan EK, Lewis BK, Yocum GT, Arbab AS: Methods for magnetically labeling stem and other cells for detection by in vivo magnetic resonance imaging. Cytotherapy 2004, 6(6):62I-625.

22. Frank JA, Miller BR, Arbab AS, Zywicke HA, Jordan EK, Lewis BK, Bryant LH Jr, Bulte JW: Clinically applicable labeling of mammalian and stem cells by combining superparamagnetic iron oxides and transfection agents. Radiology 2003, 228(2):480-487.

23. Stark DD, Weissleder R, Elizondo G, Hahn PF, Saini S, Todd LE, Wittenberg J, Ferrucci JT: Superparamagnetic iron oxide: clinical application as a contrast agent for MR imaging of the liver. Radiology 1988, 168(2):297-301.

24. Weissleder R, Hahn PF, Stark DD, Elizondo G, Saini S, Todd LE, Wittenberg J, Ferrucci JT: Superparamagnetic iron oxide: enhanced detection of focal splenic tumors with MR imaging. Radiology 1988, 169(2):399-403.

25. Rad AM, Arbab AS, Iskander AS, Jiang Q, Soltanian-Zadeh H: Quantification of superparamagnetic iron oxide (SPIO)-labeled cells using MRI. J Magn Reson Imaging 2007, 26(2):366-374

26. Arbab AS, Yocum GT, Rad AM, Khakoo AY, Fellowes V, Read EJ, Frank JA: Labeling of cells with ferumoxides-protamine sulfate complexes does not inhibit function or differentiation capacity of hematopoietic or mesenchymal stem cells. NMR Biomed 2005, 18(8):553-559.

27. Arbab AS, Pandit SD, Anderson SA, Yocum GT, Bur M, Frenkel V, Khuu HM, Read EJ, Frank JA: Magnetic resonance imaging and confocal microscopy studies of magnetically labeled endothelial progenitor cells trafficking to sites of tumor angiogenesis. Stem Cells 2006, 24(3):67I-678.

28. Yao C, Lin Y, Ye CS, Bi J, Zhu YF, Wang SM: Role of interleukin-8 in the progression of estrogen receptor-negative breast cancer. Chinese medical journal 2007, I 20(20): 1766-I772.

29. Ogan D: GeneABAAN WEC: Therapy in Human Breast Cancer. Turk J Med Sci 2002, 32:283-291.

30. Arafat WO, Casado E, Wang M, Alvarez RD, Siegal GP, Glorioso JC, Curiel DT, Gomez-Navarro ]: Genetically modified CD34+ cells exert a cytotoxic bystander effect on human endothelial and cancer cells. Clin Cancer Res 2000, 6(I I):4442-4448.

31. Wei J, Blum S, Unger M, Jarmy G, Lamparter M, Geishauser A, Vlastos GA, Chan G, Fischer KD, Rattat D, et al.: Embryonic endothelial progenitor cells armed with a suicide gene target hypoxic lung metastases after intravenous delivery. Cancer cell 2004, 5(5):477-488

32. Komarova S, Kawakami Y, Stoff-Khalili MA, Curiel DT, Pereboeva L: Mesenchymal progenitor cells as cellular vehicles for delivery of oncolytic adenoviruses. Molecular cancer therapeutics 2006 , 5(3):755-766

33. Muta M, Matsumoto G, Hiruma K, Nakashima E, Toi M: Study of cancer gene therapy using IL-I 2-secreting endothelial progenitor cells in a rat solid tumor model. Oncology reports 2003, I0(6): 1765-1769

34. Arap W, Pasqualini R: Engineered embryonic endothelial progenitor cells as therapeutic Trojan horses. Cancer cell 2004, 5(5):406-408.

35. Liu Y, Saxena A, Zheng C, Carlsen S, Xiang J: Combined alpha tumor necrosis factor gene therapy and engineered dendritic cell vaccine in combating well-established tumors. The journal of gene medicine 2004, 6(8):857-868.

36. Aboody KS, Brown A, Rainov NG, Bower KA, Liu S, Yang W, Small JE, Herrlinger U, Ourednik V, Black PM, et al.: Neural stem cells display extensive tropism for pathology in adult brain: evidence from intracranial gliomas. Proceedings of the National Academy of Sciences of the United States of America 2000, 97(23): |2846-|285|.

37. Ourednik V, Ourednik J, Park KI, Teng YD, Aboody KA, Auguste KI, Taylor RM, Tate BA, Snyder EY: Neural stem cells are uniquely suited for cell replacement and gene therapy in the CNS. Novartis Foundation symposium 2000, 23 I:242-262. discussion 262$249,302-246$

38. Brown AB, Yang W, Schmidt NO, Carroll R, Leishear KK, Rainov NG, Black PM, Breakefield XO, Aboody KS: Intravascular delivery of neural stem cell lines to target intracranial and extracranial tumors of neural and non-neural origin. Human gene therapy 2003, I (1 ( 8): : 1777-1785.

39. Nakamura $\mathrm{K}$, Ito $\mathrm{Y}$, Kawano $\mathrm{Y}$, Kurozumi K, Kobune M, Tsuda $\mathrm{H}$, Bizen A, Honmou O, Niitsu Y, Hamada H: Antitumor effect of genetically engineered mesenchymal stem cells in a rat glioma model. Gene therapy 2004, I I(I4): I I55- I I64.

40. Aboody KS, Najbauer J, Schmidt NO, Yang W, Wu JK, Zhuge Y, Przylecki W, Carroll R, Black PM, Perides G: Targeting of melanoma brain metastases using engineered neural stem/ progenitor cells. Neuro-oncology 2006, 8(2): | |9-126.

4I. Hamada H, Kobune M, Nakamura K, Kawano Y, Kato K, Honmou O Houkin K, Matsunaga T, Niitsu Y: Mesenchymal stem cells (MSC) as therapeutic cytoreagents for gene therapy. Cancer science 2005, 96(3): 149-156. 
42. Schichor C, Birnbaum T, Etminan N, Schnell O, Grau S, Miebach S, Aboody K, Padovan C, Straube A, Tonn JC, et al: Vascular endothelial growth factor A contributes to glioma-induced migration of human marrow stromal cells (hMSC). Experimental neurology 2006, 199(2):30I-3I0.

43. Nakamizo A, Marini F, Amano T, Khan A, Studeny M, Gumin J, Chen J, Hentschel S, Vecil G, Dembinski J, et al.: Human bone marrowderived mesenchymal stem cells in the treatment of gliomas. Cancer research 2005, 65(8):3307-33।8.

44. Moore XL, Lu J, Sun L, Zhu CJ, Tan P, Wong MC: Endothelial progenitor cells' "homing" specificity to brain tumors. Gene therapy 2004, II(I0):8II-8I8.

45. Ferrari N, Glod J, Lee J, Kobiler D, Fine HA: Bone marrowderived, endothelial progenitor-like cells as angiogenesisselective gene-targeting vectors. Gene therapy 2003 , I0(8):647-656.

46. Sonabend AM, Ulasov IV, Tyler MA, Rivera AA, Mathis JM, Lesniak MS: Mesenchymal stem cells effectively deliver an oncolytic adenovirus to intracranial glioma. Stem Cells 2008, 26(3):83I-84I.

47. Deng W, Jia J: Endothelial progenitor cells as cellular vehicles to deliver oncolytic virus therapies to metastatic tumors: the "Trojan horse" approach. Medical hypotheses 2008 70(4):842-844.

48. Dohan O, De la Vieja A, Paroder V, Riedel C, Artani M, Reed M, Ginter CS, Carrasco N: The sodium/iodide Symporter (NIS): characterization, regulation, and medical significance. Endocrine reviews 2003, 24(I):48-77.

49. Schipper ML, Riese CG, Seitz S, Weber A, Behe M, Schurrat T, Schramm N, Keil B, Alfke H, Behr TM: Efficacy of $99 \mathrm{mT}$ c pertechnetate and $|3| \mathrm{I}$ radioisotope therapy in sodium/iodide symporter (NIS)-expressing neuroendocrine tumors in vivo. European journal of nuclear medicine and molecular imaging 2007, 34(5):638-650.

50. Lundqvist A, Noffz G, Pavlenko M, Saeboe-Larssen S, Fong T, Maitland $N$, Pisa P: Nonviral and viral gene transfer into different subsets of human dendritic cells yield comparable efficiency of transfection. J Immunother 2002, 25(6):445-454.

51. Shayakhmetov DM, Papayannopoulou T, Stamatoyannopoulos G, Lieber A: Efficient gene transfer into human CD34(+) cells by a retargeted adenovirus vector. Journal of virology 2000, 74(6):2567-2583.

52. Kohn DB: Gene therapy using hematopoietic stem cells. Current opinion in molecular therapeutics 1999, I(4):437-442.

53. Yamasaki $\mathrm{H}$, Katoh $F$ : Further evidence for the involvement of gap-junctional intercellular communication in induction and maintenance of transformed foci in BALB/c 3T3 cells. Cancer research 1988, 48(I 2):3490-3495.

54. Wu JK, Cano WG, Meylaerts SA, Qi P, Vrionis F, Cherington V: Bystander tumoricidal effect in the treatment of experimental brain tumors. Neurosurgery 1994, 35(6): 1094-1 102.

55. Freeman SM, Abboud CN, Whartenby KA, Packman CH, Koeplin DS, Moolten FL, Abraham GN: The "bystander effect": tumor regression when a fraction of the tumor mass is genetically modified. Cancer research 1993, 53(2I):5274-5283.

56. Yasui K, Matsumoto K, Hirayama F, Tani Y, Nakano T: Differences between peripheral blood and cord blood in the kinetics of lineage-restricted hematopoietic cells: implications for delayed platelet recovery following cord blood transplantation. Stem Cells 2003, 2 I(2): I43-I5I.

57. Matsumoto K, Yasui K, Yamashita N, Horie Y, Yamada T, Tani Y, Shibata $\mathrm{H}$, Nakano $\mathrm{T}$ : In vitro proliferation potential of $\mathrm{ACI} 33$ positive cells in peripheral blood. Stem Cells 2000, 18(3): 196-203.

58. Rad AM, Janic B, Iskander AS, Soltanian-Zadeh H, Arbab AS: Measurement of quantity of iron in magnetically labeled cells: comparison among different UV/VIS spectrometric methods. BioTechniques 2007, 43(5):627-628. 630, 632 passim.

59. Soltanian-Zadeh H, Windham JP, Peck DJ: Optimal linear transformation for MRI feature extraction. IEEE transactions on medical imaging 1996, I5(6):749-767.

60. Soltanian-Zadeh H, Windham JP, Peck DJ, Yagle AE: A comparative analysis of several transformations for enhancement and segmentation of magnetic resonance image scene sequences. IEEE transactions on medical imaging 1992 I I(3):302-3।8.
61. Jacobs MA, Windham JP, Soltanian-Zadeh H, Peck DJ, Knight RA: Registration and warping of magnetic resonance images to histological sections. Medical physics 1999, 26(8): 1568-1578.
Publish with Biomed Central and every scientist can read your work free of charge

"BioMed Central will be the most significant development for disseminating the results of biomedical research in our lifetime. "

Sir Paul Nurse, Cancer Research UK

Your research papers will be:

- available free of charge to the entire biomedical community

- peer reviewed and published immediately upon acceptance

- cited in PubMed and archived on PubMed Central

- yours - you keep the copyright 